Bull. Fac .Agric., Cairo Univ., 65: 84-95 (2014).

\title{
ESTIMATE OF IRRIGATION REQUIREMENTS UNDER CLIMATE CHANGE SCENARIOS (A1 AND B1) FOR OLIVE TREES IN EGYPT
}

\author{
(Received : 30.1.2014)
}

\author{
By \\ A. A. Farag and A. A. El-Taweel ${ }^{*}$ \\ Central Laboratory for Agricultural Climate -" Olive and Fruits of Semi arid-zone Department \\ Horticultural Research Institute, Agricultural Research Center, Giza, Egypt
}

\begin{abstract}
The impacts of climate changes on irrigation requirements of olive trees under different climatic zones were studied using actual previous data of 2000 to 2007 for all studied regions. These data were used to generate the climatic data under climate change conditions by using magicclscengen. The major governorates cultivating olive trees located in five agricultural climatic regions were selected; Ismailia Governorate in the Nile Delta, Fayoum Governorate in middle Egypt and Assuit Governorate represented the in Upper Egypt. Matruh and North Sinai have large cultivation area in outside the Nile valley. Furthermore, the irrigation requirements for olive trees in all the studied regions were calculated. The target of this step was comparing the irrigation requirements of different climatic regions under current and future climate conditions. The FAO equation was used to calculating the irrigation requirements for olive trees under current and future conditions. The future climatic values (2050 and 2100) were entered to the model individually. Two climate change scenarios (A1 and B1) were used to assess the consequences of climate change on irrigation requirements for olive in two time slices (2050, and 2100). The results indicated that the highest evapotranspiration and irrigation requirement for olive trees were obtained in Assuit $11.36 \mathrm{~mm} /$ day in July and irrigation requirement $\left(4174 \mathrm{~m}^{3} /\right.$ feddan/year), respectively, followed by Fayoum 10.85 $\mathrm{mm} /$ day in July, (3997 $\mathrm{m}^{3} /$ feddan/year) under A1 scenario. While, the lowest ETo value was obtained in Fayoum $2.02 \mathrm{~mm} /$ day in January and the irrigation requirement was found to be (2942 $\mathrm{m}^{3} / \mathrm{feddan} /$ year) in Ismailia. Furthermore, A1 scenario has higher ETo and irrigation need value than B1 scenario. The ETo and irrigation requirements under 2050s were lower than those under 2100s under both tested scenarios. The highest water use efficiency (WUE) was obtained by Fayoum Governorate followed by Assuit Governorate under current climate conditions. Under climate change scenarios the highest WUE was obtained under Fayoum condition and the lowest WUE under North Sinai.
\end{abstract}

Key words: climate change scenarios, irrigation, olive trees, wue.

\section{INTRODUCTION}

Olive (Olea europaea L.) is the most adapted tree in the semiarid Mediterranean regions. The tolerance of the tree to drought, and its capacity to grow in shallow, poor quality soils, make it among the most species interesting for cultivation in arid and semiarid areas (Fernandez and Moreno 1999).

Olive oil production has historical importance throughout the Mediterranean basin where there is an evidence of human cultivation and consumption from as far back as 5,000-6,000 years ago (Vossen 2007). Traditionally, olive trees are not irrigated, but recently water application has been recognized as constructive in order to (a) increase yields in regions with traditional rain-fed olive production (Moriana et al., 2003), (b) allow high-density olive orchards and (c) expand olive production into regions where there is not enough rainfall as supplementary irrigation (Connor 2005).

Regions classified as semi-arid or arid constitute roughly one third of the total global land cover. Within these regions, water scarcity is one of the main factors limiting agricultural development. The impact of such water scarcity is amplified by inefficient irrigation practices, especially since the irrigation consumes more than $85 \%$ of the available water in these regions (Chehbouni et al., 2008). 
Agriculture productivity is affected by a number of factors of climate change including rainfall pattern, temperature hike, changes in sowing and harvesting dates, water availability, evapotranspiration and land suitability. All these factors can change yield and agricultural productivity (Kaiser et al., 1993).

The general trend of the climate change impacts was an increase in ETo values from North to south. This increase will be uneven between regions and seasons. The future climatic changes will increase the potential irrigationdemands by range of $6-16 \%$, due to the increase in ETo only by 2100s. (Hassanein et al., 2012)

Climate is the major driving force of crop production and water use (Harmsen et al., 2009). The increased air temperature and changed precipitation pattern will significantly affect crop yield and water use efficiency (Kattge and Knorr 2007).

Very little experiments were conducted in olive to evaluate the WUE under different irrigation regimes (Magliulo et al., 2003; Iniesta et al., 2009). This information is essential to evaluate the balance between benefit and costs associated with production, since water used for irrigation in most cases is expensive. Thus, the knowledge of WUE is crucial in supporting the decision to the more appropriate irrigation management when water available is scarce.

Climate change has been recognized globally as the most impending and pressing critical issue affecting mankind survival in the 21 st century. The last assessment report from the Intergovernmental Panel on Climate Change predicted an increment in mean temperature from $1.1-6.4{ }^{\circ} \mathrm{C}$ by 2100 (IPCC 2007).

The aim of this study was to estimate water requirement for olive trees under climate change scenarios (A1 and B1) for 2050s and 2100s in five different Egyptian climatic regions.

\section{MATERIAL AND METHOD}

\subsection{Cultivation area}

Table (1) shows that the total area of olive cultivation in Egypt was 202743 feddan. The cultivation area in Lower Egypt was 45465 feddan, the highest Governorate was Ismailia 19571 feddan. The Middle Egypt area was 23708 feddan where the highest Governorate was Fayoum 14890 feddan. Assuit was the highest Governorate in Upper Egypt and the cultivation area was 2976 feddan and the total area 4013 feddan in Upper Egypt. Matruh and North Sinai have large cultivation area in
Outside the Nile valley about 28960 and 43468 feddan, respectively.

Table (1): Area and Yield of the olive Fruits in Egypt in 2012.

\begin{tabular}{|l|c|c|}
\hline Governorates & $\begin{array}{c}\text { Area } \\
\text { (feddan) }\end{array}$ & $\begin{array}{c}\text { Yield } \\
\text { (ton/ feddan) }\end{array}$ \\
\hline Ismailia & 19571 & 6.606 \\
\hline Lower Egypt & 45465 & 4.667 \\
\hline \% & \multicolumn{2}{|c|}{$43 \%$} \\
\hline Fayoum & 14891 & 4.617 \\
\hline $\begin{array}{l}\text { Middle } \\
\text { Egypt }\end{array}$ & 23708 & 5.221 \\
\hline \% & \multicolumn{2}{|c|}{$63 \%$} \\
\hline Assuit & 2976 & 5.300 \\
\hline Upper Egypt & 4013 & 5.200 \\
\hline \% & \multicolumn{2}{|c|}{$74 \%$} \\
\hline Matruh & 28960 & 2.574 \\
\hline $\begin{array}{l}\text { Outside the } \\
\text { valley }\end{array}$ & 129557 & 3.518 \\
\hline \% & $22 \%$ \\
\hline North Sinai & 43468 & 2.286 \\
\hline $\begin{array}{l}\text { Outside the } \\
\text { valley }\end{array}$ & 129557 & 3.518 \\
\hline \% & \multicolumn{2}{|c|}{$34 \%$} \\
\hline Total Egypt & 202743 & 4.109 \\
\hline
\end{tabular}

Source : Agriculture Directorates of Governorates, Publisher : Economic Affairs Sector 2012

\subsection{Evapotranspiration}

The Penman - Monteith (PM) evapotranspiration (ET) equation predicts the rate of total evaporation and transpiration from the earth's surface using commonly measured weather data (solar radiation, air temperature, vapor content, and wind speed). The PM equation follows a single-layer or 'big leaf' approach, where single-surface resistance and single aerodynamic resistance terms represent the transport properties of the cropped surface.

The $\mathrm{ET}_{\mathrm{o}}$ (Potential evapotranspiration) for olive was calculated depending on historical climatic data from 5 climate stations (Ismailia, Fayoum, Assuit, Matruh and North Sinai). The historical data cover the period from $2000^{\text {th }}$ to $2009^{\text {th }}$ (about 10 years). Calculation of potential evapotranspiration was made according to the Penman-Monteith (PM) for the following formula (ASCE ,2002):

$$
\mathrm{ET}=\frac{\Delta\left(R_{\mathrm{n}}-G\right)+\rho_{\mathrm{a}} c_{\mathrm{p}}\left(e_{\mathrm{s}}-e_{\mathrm{a}}\right) / r_{\mathrm{a}}}{\left(\Delta+\gamma\left(1+\frac{r_{\mathrm{s}}}{r_{\mathrm{a}}}\right)\right) \lambda \rho_{\mathrm{w}}}
$$

where: 
$\Delta$ is the slope of the saturation vapor pressure vs. temperature curve.

$R_{n}$ is the net radiation flux at the surface.

$\mathrm{G}$ is the sensible heat exchange from the surface to the soil (positive if the soil is warming)

$\mathrm{P}_{\mathrm{a}}$ is air density.

$\mathrm{C}_{\mathrm{p}}$ is specific heat of the dry air.

$\mathrm{e}_{\mathrm{s}}$ is the saturation vapor pressure of the air at some height above the surface

$\mathrm{e}_{\mathrm{a}}$ is the actual vapor pressure of the air.

$r_{a}$ is aerodynamic resistance to turbulent heat and/or vapor transfer from the surface to some height $\mathrm{z}$ above the surface.

$\chi$ is the psychometric constant (defined later)

$r_{s}$ is a bulk surface resistance that describes the resistance to the flow of water vapor from inside the leaf, vegetation canopy, or soil to outside the surface.

$\chi$ is the latent heat of vaporization, defined as the energy required to convert a mass of liquid water into vapor (having typical units of joules per kilogram)

$\mathrm{P}_{\mathrm{w}}$ is density of liquid water.

\subsection{Estimation of Irrigation requirements for} olive tree

Most of the effects of the various weather conditions are incorporated into the ETo multiplying the reference crop evapotranspiration, ETo, by a crop coefficient, Kc according to FAO (1979) paper No. 33, the same methodology was adopted by many studies (Allen et al., 1998, Gafar, 2009).

$\mathrm{IR}=\mathrm{K}_{\mathrm{c}} * \mathrm{ET}_{\mathrm{o}} * \mathrm{LF} * \mathrm{IE} * \mathrm{R} *$ Area (Feddan) $/ 1000$

Where:

$\mathrm{IR}=$ Irrigation requirement $\left(\mathrm{m}^{3} /\right.$ feddan $)$.

$\mathrm{K}_{\mathrm{c}}=$ Crop coefficient [0.65-0.75] according to

( Allen et al., 1998 and Goldhamer et al., 1994) .

$\mathrm{ET}_{\mathrm{o}}=$ Reference crop evapotranspiration [mm/day].

$\mathrm{LF}=$ Leaching fraction (assumed 20\% of irrigation water).

$\mathrm{IE}=$ Irrigation efficiency of the irrigation system

in the field, (assumed 90\% of the total applied).

$\mathrm{R}=$ Reduction factor $(60-70 \%$ cover in this

study)

Area $=$ the irrigated area $\left(\right.$ one fedan $=4200 \mathrm{~m}^{2}$ ).

$1000=$ To convert from liter to cubic meter.

\subsection{Climate change scenarios}

The climate change data were conducted by MAGICC/SCENGEN tool to extract the projection changes in air temperature $(\Delta$ air temp) under the two IPCC's SRES scenarios (A1 and B1) that are described in Table (2). HadCM3 climate model was the base model under the two

Table (2): Description of IPCC Special Report on Emissions Scenarios(SRES).

\begin{tabular}{|l|l|}
\hline Scenario & \multicolumn{1}{|c|}{ Storylines } \\
\hline A1 & $\begin{array}{l}\text { Rapid economic growth, low population growth, rapid adoption of new } \\
\text { technologies, convergence of regions, capacity building, increased social } \\
\text { interaction, reduced region differences in per capita income. } \\
\text { Temperature increased } 1.4-6.4^{\circ} \mathrm{C}\end{array}$ \\
\hline B1 & $\begin{array}{l}\text { Convergent world with low population growth, transition to service and info } \\
\text { economy, resource productivity improvements, clean technology towards } \\
\text { global solutions } \\
\text { Temperature increased } 1.1-2.9^{\circ} \mathrm{C}\end{array}$ \\
\hline
\end{tabular}

estimate. Therefore, as ETo represents an index of climatic demand, Kc varies predominately with the specific crop characteristics and only to a limited extent with climate. This enables the transfer of standard values for $\mathrm{Kc}$ between locations and between climates. This has been a primary reason for the global acceptance and usefulness of the crop coefficient approach and the $\mathrm{Kc}$ factors developed in past studies. ETo is determined by the crop coefficient approach whereby the effect of the various weather conditions are incorporated into ETo and the crop characteristics into the Kc coefficient. In the crop coefficient approach the crop evapotranspiration, ETc, is calculated by scenarios. Each experiment extracted monthly $\Delta$ air-temp, for one of the two scenarios, for the coming years 2050s and 2100s. The resulted data from MAGICC/SCENGEN were in $5^{\circ} \mathrm{X} 5^{\circ}$ coordination grid. The future $\Delta$ air temp data were downscaled by simple statistical approach, according to the Egyptian coordinates.

\subsection{Water use efficiency (WUE)}

The water use efficiency (WUE) was calculated according to FAO (1982) as follows: The ratio of crop yield $(y)$ to the total amount of irrigation water use in the field for the growth season (IR).

WUE $(\mathrm{Kg} / \mathrm{m} 3)=\mathrm{Y}(\mathrm{kg}) / \mathrm{IR}\left(\mathrm{m}^{3}\right)$ 


\subsection{Statistical analysis}

Statistical analysis was determined by computer, using SAS program for statistical analysis. The $\mathrm{t}$ - test was used to establish whether there exist any significant differences in the Actual ETo and irrigation requrement at 2000-2007 and ETo and irrigation requrement at 2050 and 2100 under significant level 0.05 (SAS, 2000).

\section{RESULT AND DISUSSION \\ 3.1. Air temperature under current and future climate conditions}

Fig. (1) indicates the mean monthly temperature on Ismailia weather station in 20002009 year and 2050, 2100 years under A1 and B1 climate change Scenarios HadCM3 climate model. The mean temperature was $19.7^{\circ} \mathrm{C}, 22.1$ ${ }^{\circ} \mathrm{C}, 23.7^{\circ} \mathrm{C}, 21.6{ }^{\circ} \mathrm{C}$ and $22.7^{\circ} \mathrm{C}$ in $2000-2009$, 2050A1,2100A1, 2050B1 and 2100B1, respectively. The mean monthly temperature in 2050 and $2100 \mathrm{~A} 1$ increased from $1.2{ }^{\circ} \mathrm{C}$ to 3.6 ${ }^{\circ} \mathrm{C}$ and 2.4 to 5.8 than $2000-2009$ years. In addition, mean monthly temperature in 2050 and 2100B1 increased from $1.0^{\circ} \mathrm{C}$ to $3.5^{\circ} \mathrm{C}$ and 1.9 to 4.7 than 2000-2009 year.

Figs (2\&3) show the mean monthly temperature on Assuit and Fayoum weather station in 2000-2009 year and 2050,2100 years under A1 and B1 Scenarios. The mean annual temperature increased under 2050 and $2100 \mathrm{~A} 1$ Scenario $2.9{ }^{\circ} \mathrm{C}, 5.2{ }^{\circ} \mathrm{C}$ on Assuit and $2.6{ }^{\circ} \mathrm{C}$, $5.0{ }^{\circ} \mathrm{C}$ on Fayoum than 2000-2009 year. In other site B1 Scenario increased temperature in 2050 and 2100 about $2.4{ }^{\circ} \mathrm{C}, 3.8^{\circ} \mathrm{C}$ on Assuit and $2.2^{\circ} \mathrm{C}, 3.7^{\circ} \mathrm{C}$ on Fayoum than $2000-2009$ year.

Figs (4\&5) illustrate the mean monthly temperature on North Sinai and Matrouh weather station in 2000-2009 years and 2050, 2100 years under A1 and B1 Scenarios. The percentage of increase in annual mean temperature in 2050,2100 was $11.9,22$ and $10.5,16.9 \%$ under A1 and B1, respectively, on North Sinai and 12.1,21.3 and 9.9, 15.3\% under A1 and B1, respectively, on Matrouh than 20002009 year.

These results are in line with the report of IPCC (2007) which mentioned that the temperature will increase by uneven values in different climatic regions under climate change conditions. Moreover, climate change may have important impacts on agriculture. Based on the simulation of GCMS, future changes of global average temperature are expected to be between $2.8^{\circ} \mathrm{C}$ and $4.5^{\circ} \mathrm{C}$ in this century (IPCC, 2001), and some regional areas would be even warmer than the global average (Giorgi and Bi, 2005). So, both for policymakers and scientists, impacts of global warming on agriculture and water resources are referred to as an important issue (Gregory and Ingram, 2000; Fuhrer, 2003).

\subsection{ETo under current and future climate conditions}

Tables (3, $4 \& 5)$ present the monthly ETo at $2000-2009$ and two climate change Scenarios A1,B1 at 2050 and 2100 under five different climate region (Ismailia, Assuit, Fayoum, North Sinai and Matrouh).

The trend of ETo was almost the same under different climatic regions; the ETo values started low at the beginning of the year during January and February, then increased gradually and reached the highest ETo at mid of the year (June and July) and declined again at the end of the year during November and December.

Under current climate conditions (20002009) Assuit has the highest annual ETo (Table 1); while Ismailia has the lowest annual ETo (Table 3). The highest average monthly ETo value $8.4 \mathrm{~mm}$ was recorded at Assuit Governorate in July month (Table 1). On the other hand Fayoum recorded the lowest ETo value $2.02 \mathrm{~mm}$ in January month (Table 2).

The ETo increased significantly under climate change scenarios A1 and B1 at 2050 and 2100 compared to 2000-2009 in all climate regions.

The highest ETo value $11.4 \mathrm{~mm}$ was found at 2100 under A1 scenario during July at Assuit ; while the lowest ETo value $2.04 \mathrm{~mm}$ was found at Fayoum during January under B1 scenario in 2050.

From the previous results it can be concluded that the average ETo increased from 0.6 to 1.0 $\mathrm{mm} /$ day for Ismailia Governorate; in Assuit ETo increased from 0.8 to $1.4 \mathrm{~mm} /$ day; in Fayoum ETo increased from 0.7 to $1.3 \mathrm{~mm} /$ day; in North Sinai ETo increased from 0.6 to 1.1 $\mathrm{mm} /$ day, while in Matrouh ETo increased from 0.5 to 1.1 under A1 scenario in comparison with the current annual ETo. The B1 scenario increased ETo under different climate region as the following, Ismailia Governorate from 0.5 to $0.8 \mathrm{~mm}$; Assuit Governorate from 0.7 to $1.1 \mathrm{~mm}$; Fayoum from 0.6 to $1.0 \mathrm{~mm}$; North Sinai from 0.5 to $0.9 \mathrm{~mm}$ and Matrouh Governorate from 0.4 to $0.7 \mathrm{~mm}$.

These results agreed with Allen et al. (1998) who reported that other variables are related to temperatures which affect crop growth and yield, 


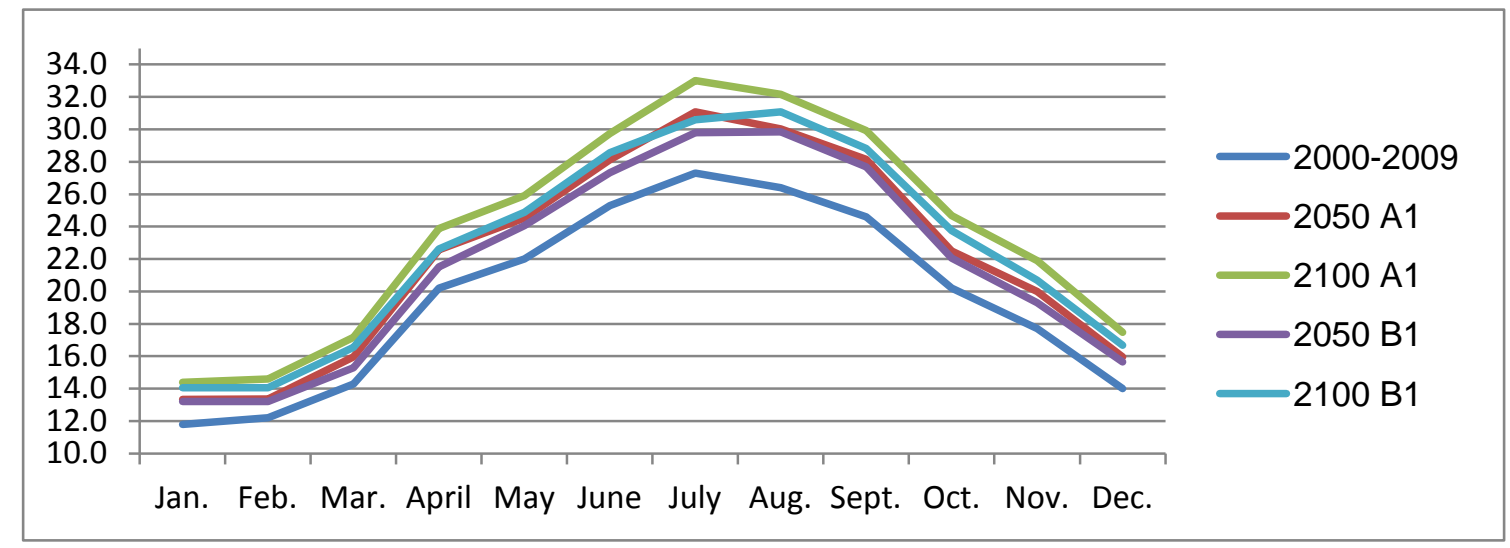

Fig. (1): Mean temperature on Ismailia weather station in 2000-2009 year and 2050, 2100 years under A1 and B1 Scenarios.

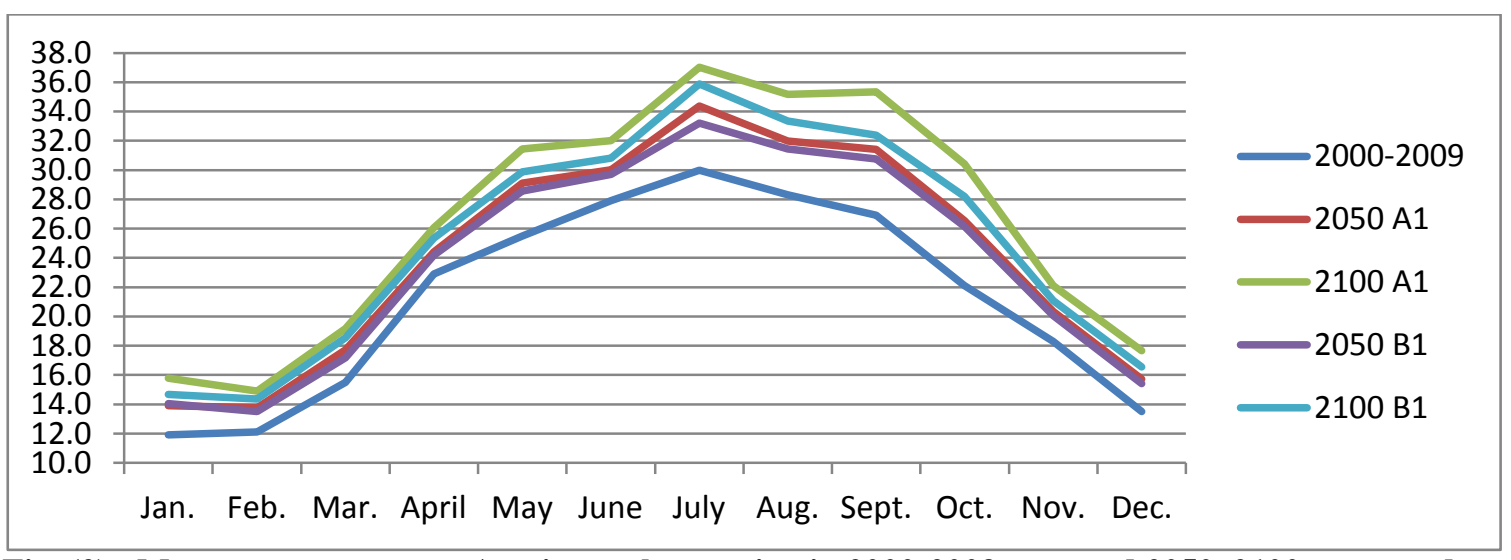

Fig. (2): Mean temperature on Assuit weather station in 2000-2009 year and 2050, 2100 years under A1 and B1 Scenarios.

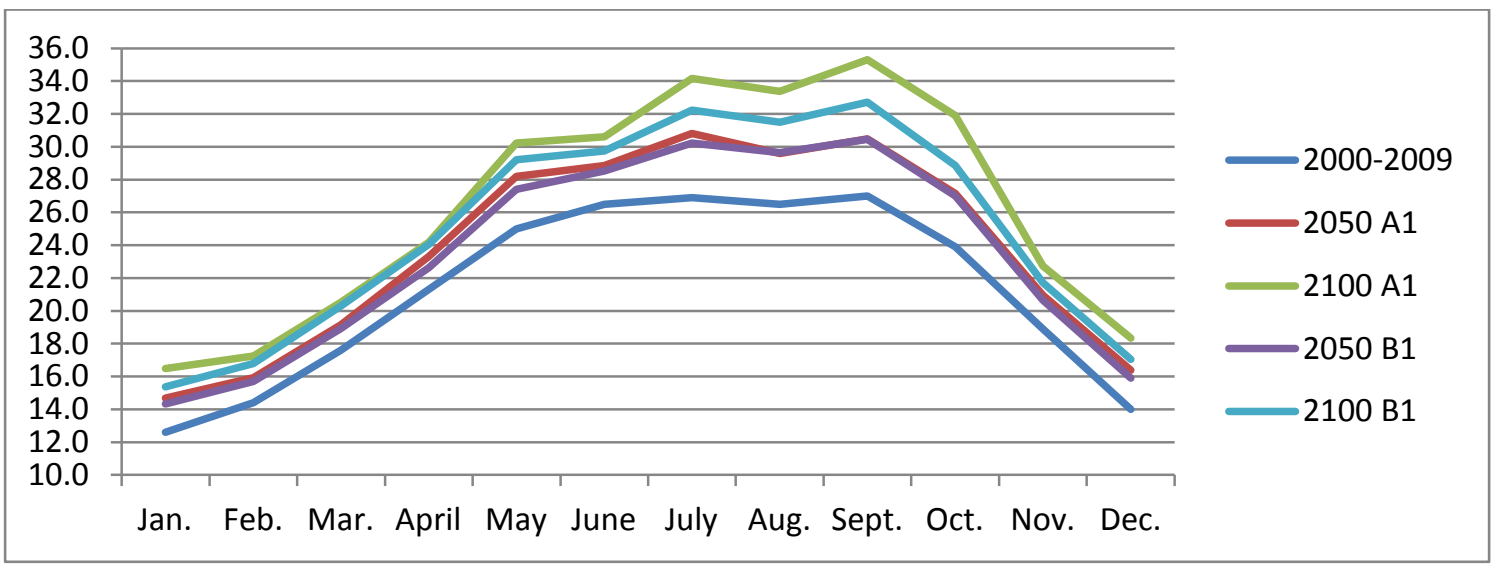

Fig. (3): Mean temperature on Fayoum weather station in 2000-2009 year and 2050, 2100 years under A1 and B1 Scenarios. 


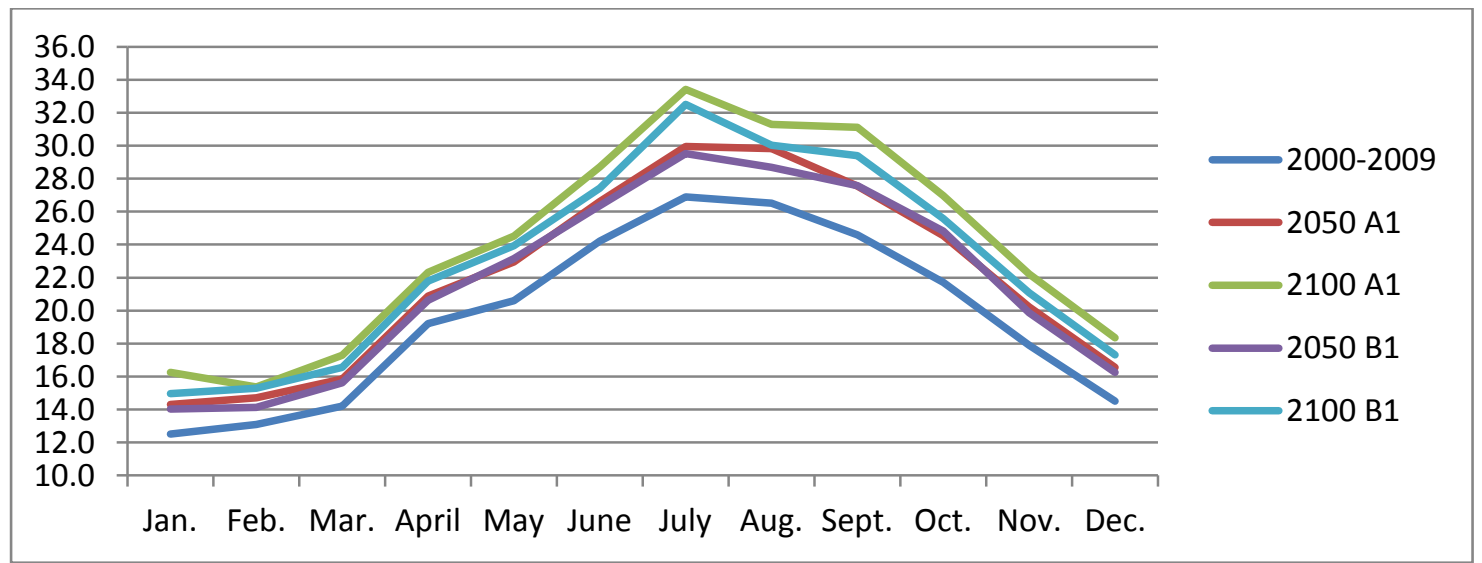

Fig. (4): Mean temperature on North Sinai weather station in 2000-2009 year and 2050, 2100 years under A1 and B1 Scenarios.

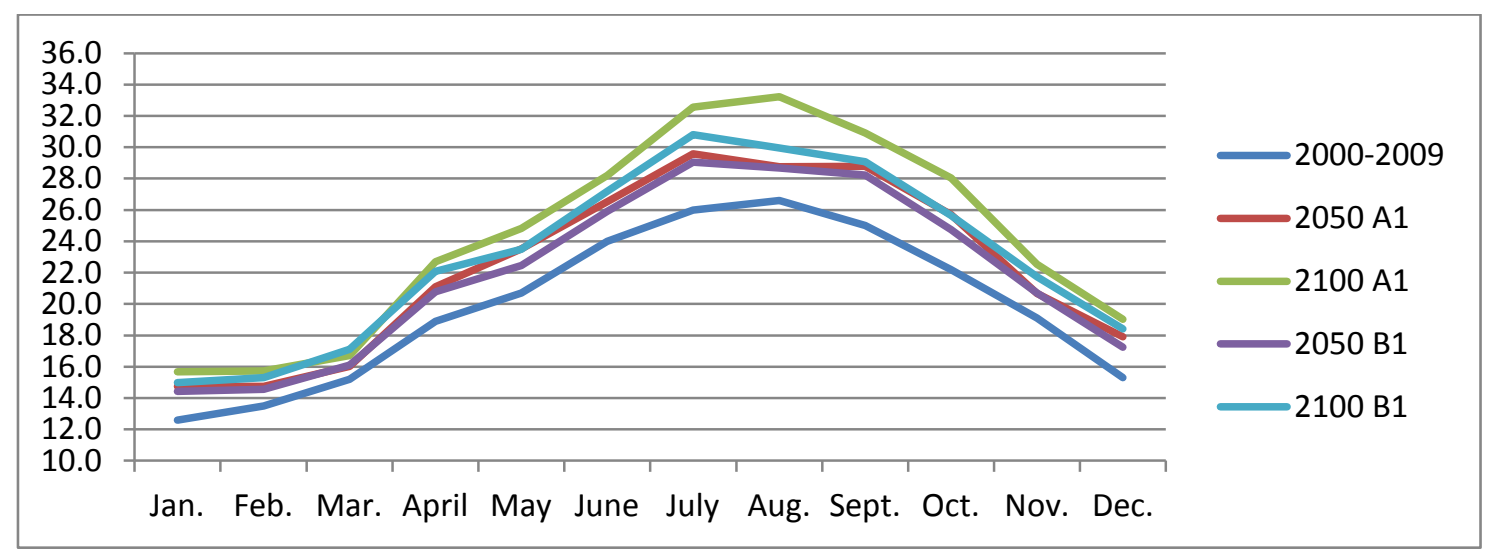

Fig. (5): Mean temperature on Matrouh weather station in 2000-2009 year and 2050, 2100 years under A1 and B1 Scenarios.

Table (3): Average monthly ETo under current and future climate conditions at Ismailia and Assuit Governorates.

\begin{tabular}{|c|c|c|c|c|c|c|c|c|c|c|}
\hline \multirow[b]{3}{*}{ Month } & \multicolumn{10}{|c|}{ ETo mm/day } \\
\hline & \multicolumn{5}{|c|}{ Ismailia } & \multicolumn{5}{|c|}{ Assuit } \\
\hline & $\begin{array}{c}2000- \\
2009\end{array}$ & $\begin{array}{c}2050 \\
\text { A1 }\end{array}$ & $\begin{array}{c}2100 \\
\text { A1 }\end{array}$ & $\begin{array}{c}2050 \\
\text { B1 }\end{array}$ & $\begin{array}{c}2100 \\
\text { B1 }\end{array}$ & $\begin{array}{c}2000- \\
2009\end{array}$ & $\begin{array}{c}2050 \\
\text { A1 }\end{array}$ & $\begin{array}{c}2100 \\
\text { A1 }\end{array}$ & $\begin{array}{c}2050 \\
\text { B1 }\end{array}$ & $\begin{array}{c}2100 \\
\text { B1 }\end{array}$ \\
\hline Jan. & 2.19 & 2.36 & 2.48 & 2.35 & 2.44 & 2.06 & 2.26 & 2.46 & 2.28 & 2.34 \\
\hline Feb. & 2.50 & 2.65 & 2.81 & 2.63 & 2.74 & 3.32 & 3.60 & 3.79 & 3.56 & 3.70 \\
\hline Mar. & 3.61 & 3.92 & 4.13 & 3.79 & 4.02 & 3.94 & 4.38 & 4.67 & 4.27 & 4.54 \\
\hline April & 4.82 & 5.39 & 5.71 & 5.14 & 5.40 & 5.57 & 5.99 & 6.45 & 5.92 & 6.25 \\
\hline May & 5.39 & 6.08 & 6.45 & 5.95 & 6.17 & 6.56 & 7.74 & 8.51 & 7.57 & 7.99 \\
\hline June & 7.17 & 8.18 & 8.76 & 7.90 & 8.34 & 7.96 & 8.81 & 9.60 & 8.68 & 9.12 \\
\hline July & 7.64 & 9.08 & 9.81 & 8.59 & 8.89 & 8.41 & 10.25 & 11.36 & 9.76 & 10.88 \\
\hline Aug. & 6.64 & 7.84 & 8.54 & 7.78 & 8.19 & 7.20 & 8.53 & 9.67 & 8.33 & 9.02 \\
\hline Sept. & 5.96 & 7.02 & 7.55 & 6.88 & 7.22 & 6.13 & 7.52 & 8.71 & 7.31 & 7.81 \\
\hline Oct. & 4.40 & 4.91 & 5.39 & 4.81 & 5.19 & 4.85 & 5.93 & 6.87 & 5.84 & 6.33 \\
\hline Nov. & 3.30 & 3.68 & 4.00 & 3.57 & 3.80 & 3.10 & 3.41 & 3.69 & 3.37 & 3.53 \\
\hline Dec. & 2.49 & 2.73 & 2.92 & 2.69 & 2.82 & 2.45 & 2.73 & 2.97 & 2.69 & 2.83 \\
\hline P-value & & $*$ & $*$ & $*$ & $*$ & & $*$ & $*$ & $*$ & $*$ \\
\hline Average & 4.7 & 5.3 & 5.7 & 5.2 & 5.4 & 5.1 & 5.9 & 6.6 & 5.8 & 6.2 \\
\hline
\end{tabular}

* significant at $\mathrm{P}<0.05$ 
Table (4): Average monthly ETo under current and future climate conditions at Fayoum and North Sinai Governorates.

\begin{tabular}{|c|c|c|c|c|c|c|c|c|c|c|}
\hline & \multicolumn{9}{|c|}{ Fayoum } & \multicolumn{7}{c|}{ ETo mm/day } \\
\cline { 2 - 13 } Month & \multicolumn{1}{|c|}{$\begin{array}{c}\mathbf{2 0 0 0} \\
\mathbf{2 0 0 9}\end{array}$} & $\begin{array}{c}\mathbf{2 0 5 0} \\
\mathbf{A 1}\end{array}$ & $\begin{array}{c}\mathbf{2 1 0 0} \\
\mathbf{A 1}\end{array}$ & $\begin{array}{c}\mathbf{2 0 5 0} \\
\mathbf{B 1}\end{array}$ & $\begin{array}{c}\mathbf{2 1 0 0} \\
\mathbf{B 1}\end{array}$ & $\begin{array}{c}\mathbf{2 0 0 0}- \\
\mathbf{2 0 0 9}\end{array}$ & $\begin{array}{c}\mathbf{2 0 5 0} \\
\mathbf{A 1}\end{array}$ & $\begin{array}{c}\mathbf{2 1 0 0} \\
\mathbf{A 1}\end{array}$ & $\begin{array}{c}\mathbf{2 0 5 0} \\
\mathbf{B 1}\end{array}$ & $\begin{array}{c}\mathbf{2 1 0 0} \\
\text { B1 }\end{array}$ \\
\hline Jan. & 2.02 & 2.07 & 2.24 & 2.04 & 2.13 & 2.29 & 2.58 & 2.93 & 2.55 & 2.66 \\
\hline Feb. & 2.39 & 2.57 & 2.73 & 2.54 & 2.67 & 2.37 & 2.48 & 2.55 & 2.41 & 2.54 \\
\hline Mar. & 3.93 & 4.23 & 4.50 & 4.19 & 4.46 & 4.14 & 4.48 & 4.77 & 4.43 & 4.62 \\
\hline April & 5.21 & 5.73 & 5.96 & 5.55 & 5.93 & 5.97 & 6.47 & 6.90 & 6.40 & 6.74 \\
\hline May & 7.44 & 8.62 & 9.38 & 8.33 & 9.00 & 7.12 & 7.96 & 8.52 & 8.03 & 8.31 \\
\hline June & 8.24 & 9.22 & 9.94 & 9.07 & 9.57 & 7.94 & 8.90 & 9.73 & 8.79 & 9.22 \\
\hline July & 7.96 & 9.51 & 10.85 & 9.28 & 10.08 & 7.50 & 8.65 & 9.94 & 8.48 & 9.59 \\
\hline Aug. & 6.55 & 7.55 & 8.79 & 7.57 & 8.18 & 6.97 & 8.13 & 8.64 & 7.73 & 8.20 \\
\hline Sept. & 5.83 & 6.85 & 8.25 & 6.84 & 7.49 & 5.60 & 6.43 & 7.42 & 6.43 & 6.94 \\
\hline Oct. & 4.39 & 5.11 & 6.15 & 5.07 & 5.48 & 4.12 & 4.71 & 5.21 & 4.77 & 4.92 \\
\hline Nov. & 3.19 & 3.52 & 3.80 & 3.47 & 3.64 & 2.94 & 3.28 & 3.57 & 3.23 & 3.40 \\
\hline Dec. & 1.74 & 1.94 & 2.11 & 1.90 & 2.00 & 2.12 & 2.34 & 2.53 & 2.31 & 2.42 \\
\hline P- value & & $*$ & $*$ & $*$ & $*$ & & $*$ & $*$ & $*$ & $*$ \\
\hline Average & $\mathbf{4 . 9}$ & $\mathbf{5 . 6}$ & $\mathbf{6 . 2}$ & $\mathbf{5 . 5}$ & $\mathbf{5 . 9}$ & $\mathbf{4 . 9}$ & $\mathbf{5 . 5}$ & $\mathbf{6 . 1}$ & $\mathbf{5 . 5}$ & $\mathbf{5 . 8}$ \\
\hline
\end{tabular}

* significant at $\mathbf{P}<0.05$

Table (5): Average monthly ETo under current and future climate conditions at Matrouh Governorate .

\begin{tabular}{|c|c|c|c|c|c|}
\hline \multirow{2}{*}{ Month } & \multicolumn{5}{|c|}{ ETo mm/day } \\
\cline { 2 - 6 } & \multicolumn{5}{|c|}{ Matrouh } \\
\cline { 2 - 6 } Jan. & $\mathbf{2 0 0 0 - 2 0 0 9}$ & $\mathbf{2 0 5 0} \mathbf{A 1}$ & $\mathbf{2 1 0 0} \mathbf{A 1}$ & $\mathbf{2 0 5 0}$ B1 & $\mathbf{2 1 0 0 ~ B 1}$ \\
\hline Feb. & 2.70 & 2.99 & 3.12 & 2.95 & 3.02 \\
\hline Mar. & 3.00 & 3.19 & 3.34 & 3.16 & 3.27 \\
\hline April & 3.80 & 3.95 & 4.09 & 3.97 & 4.16 \\
\hline May & 5.77 & 6.41 & 6.87 & 6.31 & 6.69 \\
\hline June & 6.62 & 7.55 & 7.98 & 7.20 & 7.54 \\
\hline July & 7.40 & 7.54 & 8.49 & 7.37 & 7.94 \\
\hline Aug. & 6.14 & 8.04 & 8.64 & 7.83 & 8.28 \\
\hline Sept. & 5.20 & 6.84 & 8.22 & 6.81 & 7.20 \\
\hline Oct. & 4.50 & 6.19 & 6.74 & 6.04 & 6.26 \\
\hline Nov. & 3.10 & 3.29 & 5.81 & 5.07 & 5.28 \\
\hline Dec. & 2.80 & 3.16 & 3.63 & 3.35 & 3.51 \\
\hline P- value & & $*$ & 3.32 & 3.07 & 3.24 \\
\hline Average & $\mathbf{4 . 8}$ & $\mathbf{5 . 4}$ & $\mathbf{5 . 9}$ & $\mathbf{5 . 3}$ & $\mathbf{5 . 5}$ \\
\hline
\end{tabular}

* significant at $\mathrm{P}<0.05$

such as evaporation, transpiration, and vapor pressure deficit. Even solar radiation has been shown to be related to the diurnal air temperature difference. The increasing of air temperature will lead to increase evapotranspiration that make soils need more water and increase the need for irrigation water.
3.3. Irrigation requirements for olive under current and future conditions

Data in Tables (6, 7 and 8) indicated the irrigation requirements for mature olive trees at five climate regions under $\mathrm{A} 1$ and $\mathrm{B} 1$ climate change scenarios. 
Monthly average irrigation need for mature olive trees resulted from multiplying the average monthly ETo for each climatic region by crop coefficient of mature olive trees. According to the current situation (2000-2009) one feddan of olive needs about 2942, 3232, 3114, 3116 and $2943 \mathrm{~m}^{3} /$ year of irrigation for Ismailia, Assuit, Fayoum, North Sinai and Matrouh, respectively. The highest irrigation requirement was recorded in Assuit Governorate followed by North Sinai but the lowest irrigation requirements were recorded in Ismailia and Matrouh.

The irrigation requirements under climate change increased significantly in both scenarios A1, B1 at 2050 and 2100 compared to the current situation (2000-2009). Furthermore, the B1 scenario was lower than A1 scenario in irrigation need under 2050 and 2100 years. While 2050s was lower than 2100s under both tested scenarios.

The highest increasing percentage of the estimated irrigation need was found in Assuit Governorate $29.1 \%$ followed by Fayoum
Governorate $28.4 \%$ at 2100 s under A1 scenario; while the lowest increasing percentage of the irrigation need was found in Maturoh $10.8 \%$ followed by Ismailia Governorate $11.3 \%$ at 2050 s under B1 scenario. In spite of the highest irrigation requirements for mature olive trees (cubic meter /fed.year) under current and future (2050s and 2100s) was recorded in Assuit but the lower rate of the irrigation requirements was recorded in Maturoh governorate at 2050, 2100s under A1, B1 scenarios. Similar results were reported by many authors such as Eid (1993), Eid et al. (2001) and Medany, (2001). Furthermore, projected future temperature rise is likely to increase irrigation requirements, thereby directly decreasing crop water use efficiency and increase irrigation demands of the agriculture sector. Irrigation requirements of the important strategic crops in Egypt are expected to increase by a range of 6 to $16 \%$ by 2100 . The high vulnerability of on-farm irrigation systems in Egypt is attributed to low efficacy of irrigation management patterns (EEAA, 2010).

Table (6): Average monthly irrigation requirements for mature olive trees under current and future conditions at Ismailia and Assuit Governorates.

\begin{tabular}{|c|c|c|c|c|c|c|c|c|c|c|}
\hline \multirow[b]{3}{*}{ Month } & \multicolumn{10}{|c|}{$\mathrm{m}^{3} /$ feddan } \\
\hline & \multicolumn{5}{|c|}{ Ismailia } & \multicolumn{5}{|c|}{ Assuit } \\
\hline & $\begin{array}{c}2000 \\
2009\end{array}$ & $\begin{array}{c}2050 \\
\text { A1 }\end{array}$ & $\begin{array}{c}2100 \\
\text { A1 }\end{array}$ & $\begin{array}{c}2050 \\
\text { B1 }\end{array}$ & $\begin{array}{c}2100 \\
\text { B1 }\end{array}$ & $\begin{array}{c}2000 \\
2009\end{array}$ & $\begin{array}{c}2050 \\
\text { A1 }\end{array}$ & $\begin{array}{c}2100 \\
\text { A1 }\end{array}$ & $\begin{array}{c}2050 \\
\text { B1 }\end{array}$ & $\begin{array}{c}2100 \\
\text { B1 }\end{array}$ \\
\hline Jan. & 69 & 74 & 77 & 73 & 76 & 64 & 71 & 77 & 71 & 73 \\
\hline Feb. & 71 & 75 & 79 & 74 & 77 & 94 & 101 & 107 & 100 & 104 \\
\hline Mar. & 169 & 184 & 194 & 178 & 189 & 185 & 205 & 219 & 200 & 213 \\
\hline April & 237 & 265 & 281 & 253 & 265 & 274 & 294 & 317 & 291 & 307 \\
\hline May & 295 & 332 & 353 & 325 & 337 & 359 & 423 & 466 & 414 & 437 \\
\hline June & 406 & 464 & 496 & 448 & 473 & 452 & 499 & 544 & 492 & 517 \\
\hline July & 507 & 603 & 652 & 570 & 590 & 558 & 680 & 755 & 648 & 723 \\
\hline Aug. & 441 & 520 & 567 & 517 & 544 & 478 & 566 & 642 & 553 & 599 \\
\hline Sept. & 338 & 398 & 428 & 390 & 409 & 348 & 426 & 494 & 414 & 443 \\
\hline Oct. & 206 & 230 & 253 & 226 & 243 & 227 & 278 & 322 & 274 & 297 \\
\hline Nov. & 125 & 139 & 151 & 135 & 143 & 117 & 129 & 139 & 127 & 133 \\
\hline Dec. & 78 & 85 & 91 & 84 & 88 & 77 & 85 & 93 & 84 & 88 \\
\hline P-value & & $*$ & $*$ & $*$ & $*$ & & $*$ & $*$ & $*$ & $*$ \\
\hline Total & 2942 & 3369 & 3622 & 3273 & 3436 & 3232 & 3760 & 4174 & 3670 & 3935 \\
\hline \multicolumn{2}{|c|}{$\%$} & 14.5 & 23.1 & 11.3 & 16.8 & & 16.3 & 29.1 & $\overline{13.5}$ & 21.7 \\
\hline
\end{tabular}

* significant at $\mathrm{P}<0.05$ 
Table (7): Average monthly irrigation requirements for mature olive trees under current and future conditions at Fayoum and North Sinai Governorates.

\begin{tabular}{|c|c|c|c|c|c|c|c|c|c|c|}
\hline \multirow[b]{3}{*}{ Month } & \multicolumn{10}{|c|}{$\mathrm{m}^{3} /$ feddan } \\
\hline & \multicolumn{5}{|c|}{ Fayoum } & \multicolumn{5}{|c|}{ North Sinai } \\
\hline & $\begin{array}{c}2000- \\
2009\end{array}$ & $\begin{array}{c}2050 \\
\text { A1 }\end{array}$ & $\begin{array}{c}2100 \\
\mathrm{~A} 1\end{array}$ & $\begin{array}{c}2050 \\
\text { B1 }\end{array}$ & $\begin{array}{c}2100 \\
\text { B1 }\end{array}$ & $\begin{array}{l}2000- \\
2009 \\
\end{array}$ & $\begin{array}{c}2050 \\
\text { A1 } \\
\end{array}$ & $\begin{array}{c}2100 \\
\text { A1 }\end{array}$ & $\begin{array}{c}2050 \\
\text { B1 } \\
\end{array}$ & $\begin{array}{c}2100 \\
\text { B1 } \\
\end{array}$ \\
\hline Jan. & 59 & 65 & 70 & 64 & 67 & 72 & 81 & 92 & 80 & 83 \\
\hline Feb. & 67 & 73 & 77 & 72 & 75 & 67 & 70 & 72 & 68 & 72 \\
\hline Mar. & 184 & 198 & 211 & 196 & 209 & 194 & 210 & 224 & 208 & 217 \\
\hline April & 256 & 282 & 293 & 273 & 291 & 293 & 318 & 339 & 314 & 331 \\
\hline May & 407 & 471 & 513 & 456 & 492 & 389 & 435 & 466 & 439 & 454 \\
\hline June & 467 & 523 & 563 & 514 & 543 & 450 & 505 & 552 & 499 & 523 \\
\hline July & 528 & 631 & 720 & 616 & 669 & 498 & 574 & 660 & 563 & 637 \\
\hline Aug. & 435 & 502 & 584 & 503 & 543 & 463 & 540 & 574 & 514 & 544 \\
\hline Sept. & 331 & 388 & 468 & 388 & 425 & 318 & 364 & 421 & 365 & 393 \\
\hline Oct. & 206 & 239 & 288 & 238 & 257 & 193 & 221 & 244 & 223 & 231 \\
\hline Nov. & 121 & 133 & 144 & 131 & 138 & 111 & 124 & 135 & 122 & 129 \\
\hline Dec. & 54 & 61 & 66 & 59 & 63 & 68 & 73 & 79 & 72 & 76 \\
\hline P-value & & $*$ & $*$ & $*$ & $*$ & & $*$ & $*$ & $*$ & $*$ \\
\hline Total & 3114 & 3566 & 3997 & 3509 & 3772 & 3116 & 3514 & 3857 & 3466 & 3690 \\
\hline \multicolumn{2}{|l|}{$\%$} & 14.5 & 28.4 & 12.7 & 21.1 & & 12.8 & 23.8 & 11.3 & 18.4 \\
\hline
\end{tabular}

* significant at $\mathbf{P}<0.05$

Table (8): Average monthly irrigation requirements for mature olive trees under current and future conditions at Matrouh Governorate.

\begin{tabular}{|c|c|c|c|c|c|}
\hline \multirow[b]{3}{*}{ Month } & \multicolumn{5}{|c|}{$\mathrm{m}^{3} /$ feddan } \\
\hline & \multicolumn{5}{|c|}{ Matrouh } \\
\hline & 2000-2009 & $2050 \mathrm{~A} 1$ & $2100 \mathrm{A1}$ & 2050 B1 & $2100 \mathrm{B1}$ \\
\hline Jan. & 84 & 93 & 97 & 92 & 94 \\
\hline Feb. & 85 & 90 & 94 & 89 & 92 \\
\hline Mar. & 178 & 185 & 192 & 186 & 195 \\
\hline April & 284 & 315 & 338 & 310 & 329 \\
\hline May & 362 & 413 & 436 & 394 & 413 \\
\hline June & 405 & 456 & 490 & 444 & 470 \\
\hline July & 425 & 501 & 564 & 490 & 527 \\
\hline Aug. & 410 & 454 & 546 & 452 & 478 \\
\hline Sept. & 295 & 351 & 382 & 342 & 355 \\
\hline Oct. & 211 & 248 & 272 & 238 & 247 \\
\hline Nov. & 117 & 126 & 137 & 126 & 133 \\
\hline Dec. & 87 & 99 & 104 & 96 & 101 \\
\hline P-value & & $*$ & $*$ & $*$ & $*$ \\
\hline Total & 2943 & 3331 & 3652 & 3260 & 3434 \\
\hline \multicolumn{2}{|c|}{$\%$} & 13.2 & 24.1 & 10.8 & 16.7 \\
\hline
\end{tabular}

* significant at $\mathrm{P}<0.05$ 


\subsection{Water use efficiency (water productivity)}

Data in Table (9) showed that increasing irrigation quantity under different climate change scenarios led to a decrease water use efficiency for all governorates. The highest WUE obtained in Fayoum Governorate followed by Assuit Governorate under current climate condition. The lowest WUE was obtained in North Sinai Governorate. On the other hand, under climate change scenarios the highest WUE was obtained in Fayoum Governorate followed ranged from 331 to $680 \mathrm{~m}^{3}$ at Ismailia Governorate, 438 to $942 \mathrm{~m}^{3}$ at Assuit Governorate ; from 395 to $883 \mathrm{~m}^{3}$ at Fayoum Governorate; from 351 to $741 \mathrm{~m}^{3}$ at North Sinai Governorate and from 317 to $709 \mathrm{~m}^{3}$ at Matrouh Governorate. Water use efficiency decreased under climate change scenarios in all regions at 2050s and 2100s. More studies are needed on the impacts of climate change on olive yield and olive oil production under Egyptian conditions.

Table (9): Water use efficiency WUE (Water productivity) kilogram olive per cubic meters water at Ismailia, Fayoum, Assuit, Matrouh and North Sinai Governorates.

\begin{tabular}{|c|c|c|c|c|c|}
\hline Year & 2000-2009 & $2050 \mathrm{~A} 1$ & $2100 \mathrm{~A} 1$ & 2050 B1 & $2100 \mathrm{~B} 1$ \\
\hline \multicolumn{6}{|c|}{ Ismailia } \\
\hline Irrigation $\mathbf{~ m}^{3}$ & 2942 & 3369 & 3622 & 3273 & 3436 \\
\hline WUE $\left(\mathrm{Kg} / \mathbf{m}^{\mathbf{3}}\right)$ & 1.59 & 1.39 & 1.29 & 1.43 & 1.36 \\
\hline \multicolumn{6}{|c|}{ Fayoum } \\
\hline Irrigation $\mathbf{m}^{3}$ & 3114 & 3566 & 3997 & 3509 & 3772 \\
\hline WUE $\left(\mathrm{Kg} / \mathbf{m}^{\mathbf{3}}\right)$ & 1.68 & 1.46 & 1.31 & 1.49 & 1.38 \\
\hline \multicolumn{6}{|c|}{ Assuit } \\
\hline Irrigation $\mathbf{m}^{\mathbf{3}}$ & 3232 & 3760 & 4174 & 3670 & 3935 \\
\hline WUE $\left(\mathrm{Kg} / \mathbf{m}^{\mathbf{3}}\right)$ & 1.61 & 1.38 & 1.25 & 1.42 & 1.32 \\
\hline \multicolumn{6}{|c|}{ Matrouh } \\
\hline Irrigation $\mathbf{m}^{3}$ & 2943 & 3331 & 3652 & 3260 & 3434 \\
\hline WUE $\left(\mathrm{Kg} / \mathbf{m}^{3}\right)$ & 1.20 & 1.06 & 0.96 & 1.08 & 1.02 \\
\hline \multicolumn{6}{|c|}{ North Sinai } \\
\hline Irrigation $\mathbf{~ m}^{3}$ & 3116 & 3514 & 3857 & 3466 & 3690 \\
\hline WUE $\left(\mathrm{Kg} / \mathrm{m}^{3}\right)$ & 1.13 & 1.00 & 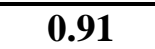 & 1.02 & 0.95 \\
\hline
\end{tabular}

by Ismailia governorate. The lowest WUE was obtained in North Sinai Governorate. The high evapotranspiration under climate change makes WUE of olive in Egypt becoming the lowest compared with WUE under current condition. There were a different in productivity of olive between Governorates. The water productivity (WP) increases as ET decreases and, therefore, one can find an economic optimum, in terms of ET and therefore of irrigation amount (Moriana et al., 2003)

\section{In conclusion}

From the obtained results it can be concluded that irrigation needs to increase depending on regions and climate change scenarios. The total amount of irrigation increase per fedden per year

\section{REFERENCES}

Allen R.,Pereira L. S., Raes D., Smith M. (1998).Crop evapotranspiration-guidelines for computing crop water requirementsFAO irrigation and drainage paper 56, FAO, Rome.

http://www.fao.org/docrep/X0490E/X049 0E00.htm.

ASCE (2002). The ASCE Standardized Reference Evapotranspiration Equation. Report of the Task Committee on Standardization of Reference Evapotranspiration, Environmental and Water Resources Institute of the American Society of Civil Engineers. Reston, VT: ASCE Publications. 
Chehbouni A., Er-Raki S., Hoedjes J., Ezzahar J., Duchemin B., Jacob F. (2008). Improvement of FAO-56 method for olive orchards Through sequential assimilation of thermal infrared based estimates of ET. Agric. Water Manag. 95: 309-321.

Connor D.J. (2005). Adaptation of olive (Olea europea L.) to water limited environment. Aust. J. Agric. Res. 56:1181-1189.

EEAA (2010). EGYPT SECOND NATIONAL COMMUNICATION. Environmental Affairs Agency, Egypt.

Eid H. M.(1993). Effect of environmental conditions and crop management on simulated peanut yield in the New Land. J. Agric. Sci., 18 (5): 1280-1287.

Eid H. M., EI-Marsafawy S. M., El-Tantawy M. M., Mesiha W. and Gad El-Rab G. M. (2001). Estimation of water needs for vegetable crops in the New Lands, Meterol. Res. Bult, EMA, 6:15 - 179.

FAO (1979). Yield Response to water. FAO Irrigation and Drainage paper No. 33 (Doorenbos, Jand Kasam, A.H.) Rome Italy.

FAO (1982). Crop water requirements irrigation and drainage. Paper No. 24, Rome, Italy.

Fernandez J.E. and Moreno F. (1999). Water use by the olive tree. J. Crop Product. 2 (2): $101-162$.

Fuhrer J. (2003). "Agroecosystern responses to combinations of elevated $\mathrm{CO} 2$, ozone, and global climate change." Agriculture Ecosystems and Environment 97:1-20.

Gafar K. (2009). Egypt. Meteorol. Authority International Meteorological Res. Bull. ISSN 1687 - 1014 - Vol. 24

Giorgi F. and Bi X.Q. (2005). Updated regional precipitation and temperature changes for the 21st century from ensamples of recent AOGCM simulations. Geophysics Res. Lett. 32, L21715.

Goldhamer D.A., Dunai J. and Ferguson L.F. (1994). Irrigation requirements of olive trees and responses to sustained deficit irrigation. Acta Hortic. 356:172-175.

Gregory P.J., and Ingram J.S.I. (2000). Food and Forestry: Global Change and Global Challenges. Agric., Ecosyst. and Environ. (Special Issue) (82): 1-394.

Harmsen E. W., Miller N. L., Schlegel N. J. and Gonzalez J. E. (2009). Seasonal climate change impacts on evapotranspiration, precipitation deficit and crop yield in
Puerto Rico. Agric. Water Manage. 96: 1085-1095.

Hassanein M. K., Elsayed M.and Khalil A. A. (2012). Impacts of sowing date, cultivar, irrigation regimes and location on bread wheat production in Egypt under climate change conditions. Nature and Science, 10 (12): 142-150.

Iniesta F., Testi L., Orgaz F. and Villalobos F.J. (2009). The effects of regulated and continuous deficit irrigation on the water use, growth and yield of olive trees. Eur J Agron 30:258-265.

Intergovernmental Panel on Climate Change (IPCC). (2007). Summary for Policymakers. In Parry, M.L., Canziani, O.F., Palutikof, J.P., van der Linden, P.J. \& Hanson, C.E., eds. Climate Change 2007: Impacts, Adaptation and Vulnerability. Contribution of Working Group II to the Fourth Assessment Report of the Intergovernmental Panel on Climate Change, pp. 7-22. Cambridge University Press, Cambridge, UK.

Intergovernmental Panel on Climate Change (IPCC). (2001). Climate change 2001: Impact, Adaptation and Vulnerability, Contribution of Working Group II to the Third Assessment Report of the IPCC, Cambridge Univ. Press, Cambridge, UK.

Kaiser H. M., Riha S. J., Wilks D. S., Rossiter D. G. and Sampath R. (1993). A farmlevel analysis of economic and agronomic impacts of gradual climate warming. American J. Agric. Econ., 75: 387-398.

Kattge J. and Knorr W. (2007). Temperature acclimation in a biochemical model of photosynthesis: a reanalysis of data from 36 species. Plant Cell Environ., 30: 11761190.

Magliulo V., d'Andria R., Lavini A., Morelli G. and Patumi M. (2003). Yield and quality of two rainfed olive cultivars following shifting to irrigation. J Hortic Sci Biotechn., 78:15-23.

Medany M. (2001). The impact of climatic change on production of different cultivars of maize, Meteorological Research Bulletin, Egyptian Meteorological Authority, 16: 194-206.

Moriana A., Orgaz F., Pastor M. and Fereres E. (2003). Yield responses of a mature olive orchard to water deficit. J. Am. Soc .Hort. Sci. 128:425-431. 
SAS (2000). Statistical Analysis System, SASUser's Guide: Statistics. SAS Institute Inc. Editors, Cary, NC.
Vossen P. (2007). Olive oil: history, production and characteristics of the world's classic oils. HortSci. 42:1093-1110.

\author{
الاحتياجات الاروائية للزيتون تحت ظروف سيناريوهات تغير المناخ (A1 , B1 ) في مصر \\ * احمد عوني احمد فرج - عبد العزيز احمد الطويل

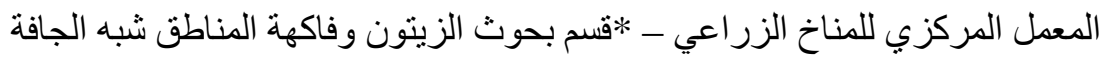

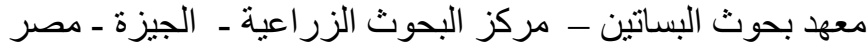

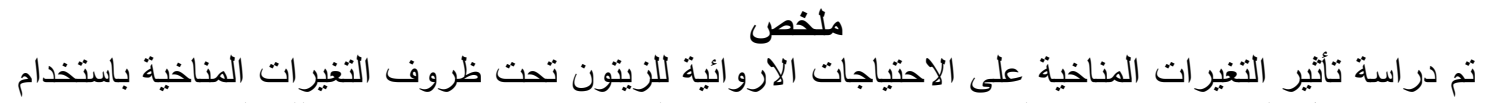

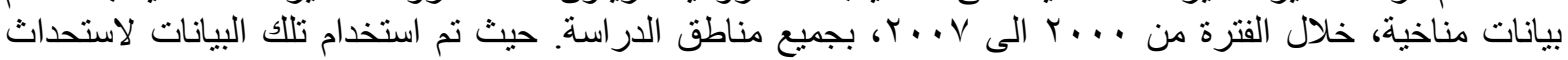

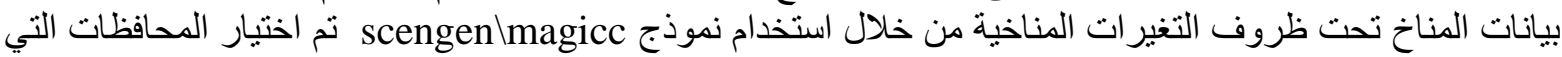

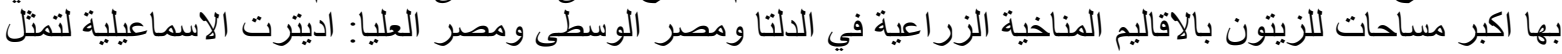

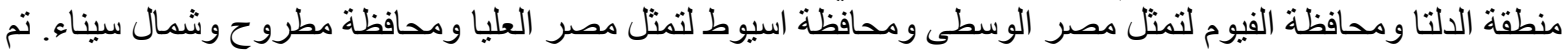

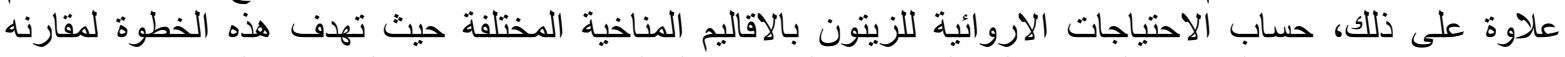

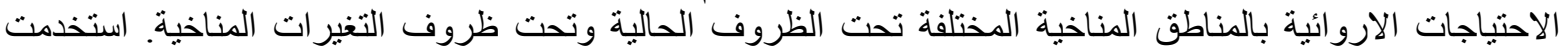
طريقة الفاو

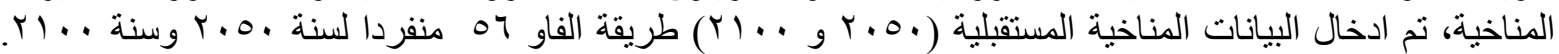

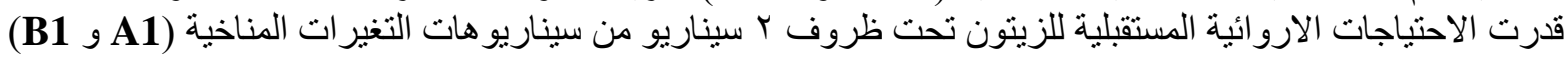

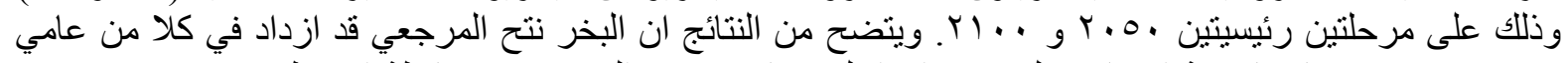

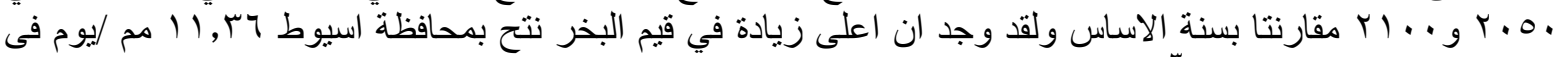

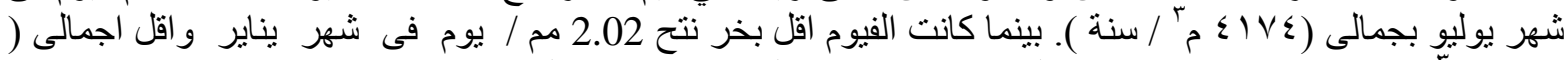

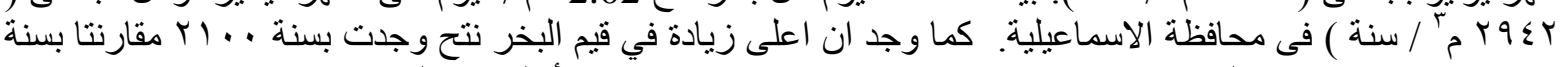

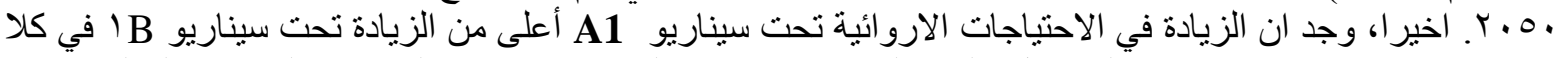

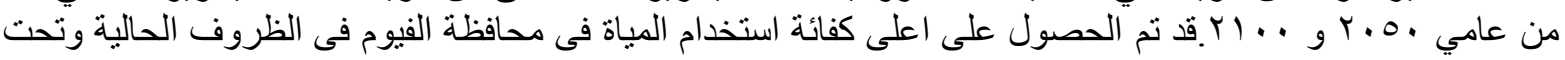
ظروف تعير المناخ يليها محافظة اسيوط تحت الظروف الحالية. وكانت محافظة شمال سيناء اقل كفاءة فى استخدام المياة تحت ظروف تغير المناخ.

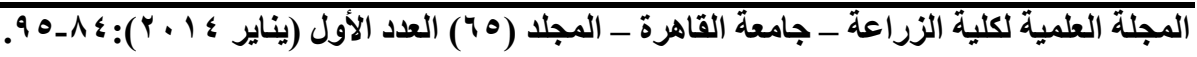

